IJAMSR 2 (1) www.ijamsr.com CrossRef: https://doi.org/10.31426/ijamsr.2019.2.1.115

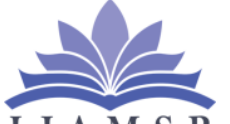

International Journal of

I J A M S R

Advanced Multidisciplinary Scientific Research (IJAMSR) ISSN:2581-4281

\title{
Professional Attitude of Secondary School Teachers
}

\author{
Showkat Ahmad Lone \\ Research Scholar, Dept. of. Education, Jiwaji University, Gwalior, M.P., India
}

Email: Loneshowkat440@gmail.com

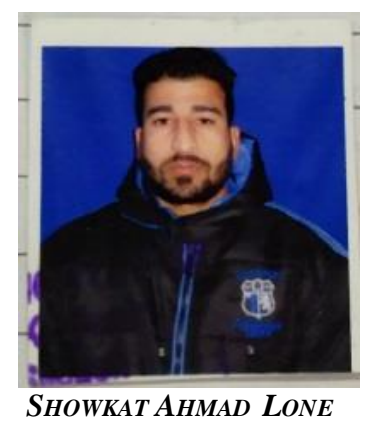

Keywords:

Professional Attitude,

Ahluwalia's Teacher Attitude

Inventory, differences in Attitudes of teachers.

\begin{abstract}
A B S T R A C T
The study aimed to find the difference in attitude of teachers towards teaching on the basis of gender, stream and locality. The sample for the study consisted of 200 secondary school teachers selected through simple random sampling technique from district Srinagar and district Kupwara of Jammu and Kashmir State. The 'Ahluwalia's Teacher Attitude Inventory' was used for the present study. The sample consists of 200 secondary school teachers. Data analysis is based on the mean score obtained from the respondents. For statistical analysis t-test was used to determine whether there are significant differences in Attitudes of teachers.
\end{abstract}

Citation: Showkat Ahmad Lone (2019). Professional Attitude of Secondary School Teachers. International Journal of Advanced Multidisciplinary Scientific Research (IJAMSR ) ISSN:2581-4281, 2 (1), January, 2019, \# Art.1115, pp 28-32

\section{Introduction}

Attitude refers to "a psychological tendency that is expressed by evaluating a particular entity with some degree of favor or disfavor" (Eagly \& Chaiken, 1993). Fishbein (1967) defines it as a mental disposition of the human individual to act for or against a definite object. Allport (1935) defines it as a mental and a neural state of readiness, organized through experience, exerting a directive or dynamic influence upon the individual's response to all objects and situations with which it is related. The attitude has been described as a learned predisposition to respond in a favorable or unfavorable manner with respect to a given attitude object (Oskamp and Schultz, 2005). Attitude refers to "a psychological tendency that is expressed by evaluating a particular entity with some degree of favor or disfavor" (Eagly \& Chaiken, 1993). Fishbein (1967) defines it as a mental disposition of the human individual to act for or against a definite object. Allport (1935) defines it as a mental 


\section{International Journal of Advanced Multidisciplinary Scientific Research (IJAMSR) ISSN:2581-4281}

and a neural state of readiness, organized through experience, exerting a directive or dynamic influence upon the individual's response to all objects and situations with which it is related. The attitude has been described as a learned predisposition to respond in a favorable or unfavorable manner with respect to a given attitude object (Oskamp and Schultz, 2005). Education in the largest sense is an act or an experience that has a formative effect on the mind, character or physical ability of an individual. In its technical sense, education is the process by which society deliberately transmits its accumulated knowledge, skills and values from one generation to another society. Education in real sense is to humanize humanity and to make life progressive cultured and civilized. It is very important for the progress of the individual and society. It is through education that man develops his thinking and reasoning, problem solving, intelligence and creativity and aptitude, positive sentiments and skills, good values and attitudes. Education is a dialogue between the past, present and the future, so that the coming generations receive the accumulated lessons of the heritage and carry it forward (UNESCO, 1998).

Attitude means the individual's prevailing tendency to respond favorably or unfavorably to an object, person or group of people, institutions or events. Attitude can be positive (values) or negative (prejudice). The attitude has been defined in many different ways over the years. The attitude of the teacher has an impact on the behavior of the student in the classroom as well. The teacher spends most of the school day in the close association with his students and as a result of this; his basic attitudes and actions, his tastes and mannerism have great influence on the students. The teachers create the emotional climate in the classroom just by being friendly calm or nervous. This directly affects the children because children learn attitudes and behavior mostly by example. The effectiveness of education depends upon the quality of teachers working in an institution. The quality of teachers in turn depends upon the quality of training received by them in different training institutions. The teacher spends most of the school day in close associations with his students and as a result of this, his basic attitudes and actions, his tastes and mannerism have great influence on the students, the teacher creates the emotional climate in the classroom just by being friendly, calm and nervous. This directly affects the children because children learn attitudes and behavior mostly by examples, emotion, tension, For example, is contagious; a teacher who is fear full and generally hostile can induce fear, worry, and insecurity in his students. The effectiveness of teacher, mainly depends upon the character, ability and his attitude towards his profession teaching. It is true that the attitude of a person towards his profession plays an important role in achieving desirable success. The attitude of a person depends upon his emotions and feelings. Renu and Nand, ( 1999) conducted a study on the attitude of effective teachers towards teaching profession .The main findings of her study were the effective teachers possess better teaching skills than less effective teachers. Their academic scores are high. They are more cooperative with students (Panday, R and Tripathy, 2006) conducted a study on the attitude of efficient school teachers. The findings indicate that there are good results of education by effective teachers. They have direct influence on the personality of students. The effectiveness of education depends upon quality teachers working in institutions. The quality of teachers in turn depends upon the quality of training received by them in different training institutions. As we know that 
qualitative and quantitative improvements of elementary and secondary educations has raised problems of solutions of right type of teachers and enriching program of teacher preparation. Thus necessities, but also to inculcate in them desirable teacher like qualities.

\section{Gender and Attitude towards teaching:}

Gender and Attitude towards teaching comprises both male and female teachers. It has always been a concern for researchers that whether male teachers have more favorable professional attitude towards teaching or female teachers. Researches (Singh, 1974; Wera, 1982; Patil, 1984; Som, 1984; Srivastav, 1989; Naik \& Pandey, 1997; Singh, 1997; Gupta, 2000; Hussain, 2004; Guneyli \& Aslan, 2009; Ghos \& Bairagya, 2010; Kooce, Aydin \& Yildiz 2010; Marry \& Samuel, 2011 \& Rocked, 2011) found significant differences in Attitude of male and female teachers towards teaching.

\section{Loyalty and Attitude towards teaching:}

Some of researcher conducted studies to compare the attitude with locality context. Teachers with urban origin were observed having more teaching attitude than that of their rural counterparts (Samantaroy, 1971). It was supported by Wera (1982) that professional attitude of urban teachers was more favorable than that of rural teachers. Tripathi (1978) found no significant difference in professional attitudes of teachers belonging college of rural and urban.

\section{Educational stream and attitude towards teaching:}

Educational stream Arts and Science were taken as a variable to see its contribution in teaching attitude in several studies. In some studies like (Üstüner, Demirtas \& Comert, 2009; Benjamine et al., 2011; Akbaba, 2013
\& Khan, Nadeem and Basu, 2013) it was revealed that stream of study differentiated the teaching attitude. Benjamin et al. (2011) observed science B.Ed. trainees had more favorable attitude towards teachings than that of arts stream. It was supported by Khan, Nadeem and Basu (2013) with sample of female teacher at higher secondary level. Significant differences were observed among students of different type of the department/program they study (Ustüner, Demirtas \& Cömert, 2009). Akbaba, (2013) found a pre - service teacher of social studies had positive teaching attitude. Conversely, some of the studies (Banerjee \& Behera, 2014; Chakraborty \& Mondal, 2014; Incik \& Kilic, 2014; Maheshwari, 2014) revealed no significant difference among the stream of study. Banerjee and Behera (2014) added that no significant difference was observed in attitudes towards teaching profession between social science and general science teacher. It was supported by Chakraborty and Mondal (2014) with sample of arts and science streams.

\section{Objectives for the study}

- The following objectives were formulated for the proposed study

- To assess the professional attitude of secondary school teachers.

- To compare the professional attitude of male and female secondary school teachers.

\section{Delimitation}

The present study was confined only to the government secondary school teachers of district Srinagar and district Kupwara. Only those teachers who were teaching Arts and Science subject streams were included in the 
IJAMSR 2 (1) www.ijamsr.com CrossRef: https://doi.org/10.31426/ijamsr.2019.2.1.115

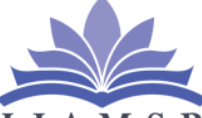

\section{International Journal of}

I J A M S R

\section{Advanced Multidisciplinary Scientific Research (IJAMSR) ISSN:2581-4281}

study. Only those teachers who were teaching class IX and $\mathrm{X}$ were included in the study.

The schools imparting general education was taken in the study. The institutions giving special or any other type of education (i.e. sports, technical, professional, religious etc.) were not included in this study

\section{Methodology}

This is a descriptive study, which examined the sample consisting of 200 secondary school teachers in Kashmir. Data analysis is based on the mean score obtained through the respondents. For statistical analysis t-test was used to determine whether there are significant differences in Attitude levels of secondary school teachers according to Gender, Stream and Locality. 'Ahluwalia's Teacher Attitude Inventory' was used to collect the data from sample subjects.

\section{Statistical analysis}

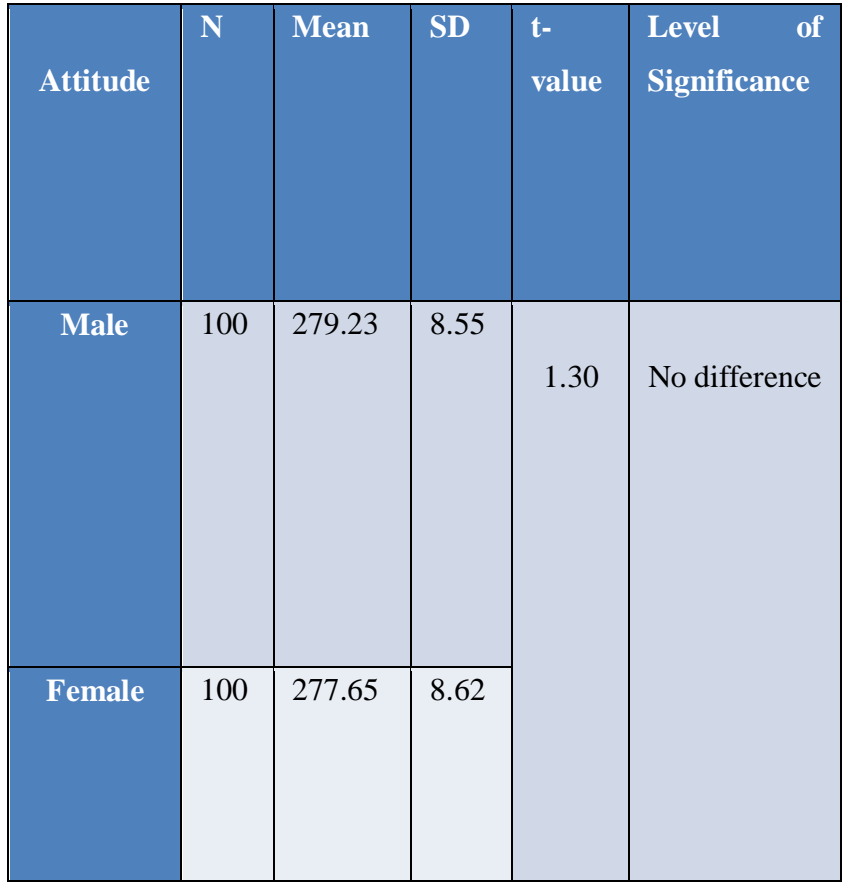

The above table shows the results of analysis of different levels of Attitude according to the sex of the respondents. The overall findings of the analysis show that there is no significant difference in the level of attitude of male and female teachers. Thus, the objective of the study, that is, "To find out the difference between male and female teachers on attitude" has been accomplished. In view of the above mentioned results the hypothesis that "there is no significant difference between male and female teachers in their attitude" is accepted. The above table shows the results of analysis of different levels of attitude, according to the locality of the respondents. The overall findings of the analysis show that there is no significant difference in the level of attitude of Rural and Urban teachers. Thus, the objective of the study, that is, "To find out the difference between Rural and Urban teachers on attitude" has been accomplished. In prospect of the above mentioned results the hypothesis that "there is no substantial difference between Rural and Urban teachers in their attitude" is assumed.

Male and female secondary school teachers do not differ significantly on attitude towards teaching. There is an insignificant difference in the attitude of secondary school teachers with respect to their area of specialization. Rural and urban secondary school teachers do not differ significantly on attitude towards teaching. 
IJAMSR 2 (1) www.ijamsr.com CrossRef: https://doi.org/10.31426/ijamsr.2019.2.1.115

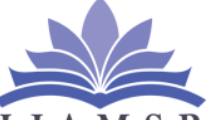

\section{International Journal of Advanced Multidisciplinary Scientific Research (IJAMSR) ISSN:2581-4281}

\section{References:}

1) Diuguid, Darraya.R. in( 2009). Studied Student Teachers Awareness, Preparedness and Attitudes of Issues Related to high Poverty Schools. . Journal of Experimental Education June 1955.

2) Christen, M., Ayer, G. and Sober man, D. (2006). Job Satisfaction, Job Performance, and Effort: A Reexamination Using Agency Theory, Journal of Marketing, January, Vol. 70, pp. 137-15

3) Davis, K. and Nostrum, J.W. (1985). Human Behavior at work: Organizational Behavior, 7 editions, McGraw Hill, New York, p.109

4) Herzberg, H. F. (1976). Motivation-Hygiene Profiles, p. 20 George, J.M. and Jones, G.R. (2008). Understanding and Managing Organizational behavior, Fifth Edition, Pearson/Prentice Hall, New Yersey, p. 78

5) Hop pock, R. (1935). Job Satisfaction, Harper and Brothers, New York, p. 47

6) Kaminski, B.S. (2007). Encyclopedia of Business and Finance, Second edition, Thompson Gale, Detroit, p. 446

7) Lawler, E.E. III and Porter, L.W. (1967). The Effect of Performance on Job Satisfaction, Industrial Relations, pp. 20-28

8) Locke, E.A. and Latham, G.P. (1990). A theory of goal setting and task performance, Prentice Hall, p.4 Lufthansa, F. (1998). Organizational Behavior, 8 Editions, McGraw-Hill/Irwin, Boston, p. 147

9) Mullins, J.L. (2005). Management and organizational behavior, Seventh Edition, Pearson Education Limited, Essex, p. 700

10) Mrunalini, T. \& Sankaraih.B. (2010). Study on Attitudes and Reflections of Prospective Teachers on Environmental Concerns. Social psychology of Education, 6,61-90.

11) Panday, $R$ and Tripathy,(2006). Attitude towards teaching, Harper and Brothers, New York, p. 47
12) Rue, L.W. and Byers, L. (2003). Management, Skills and Application, 10 ed., McGraw-Hill/Irwin, New York, p. 259

13) Renu and Nanda (1999) ). A theory of goal setting and task performance, Prentice Hall, p.4

14) Specter, P.E. (1997). Job satisfaction: Application, assessment, causes and consequences, Thousand Oaks, Corsage Publications, Inc Stat, D. (2004). The Rutledge Dictionary of Business Management, Third edition, Rutledge Publishing, Detroit, p. 78

15) Sweeney, P.D. and McFarlin, D.B. (2005). Organizational Behavior, Solutions for Management, McGraw-Hill/Irwin, New York. 57

16) Sunitha and Badola, ( 2010). Study on studied, IGNOU (B.ED.)Teacher Trainees Attitude towards Awareness of the Fundamental Rights of Secondary school Students rights of secondary school students. . Journal of Higher Education Policy Management, vol.21, no.2,pp. 203-214.

17) Selvaraj Gnanaguru, A \& Suresh Kumar,M, in( 2008). Study on under Achievement of B.Ed Students in Relation to their Home Environment and Attitude towards Teaching. . Journal of Higher Education Policy Management, vol.21, no.2,pp. 203-214.

18) UNESCO, (1998). World Declaration on Education for All. Adapted by the World conference on Education for All meeting Basic Learning Needs. Jomtin, Published by UNESCO. 